\title{
Effect of some socio-economic activities on fish diversity of lagoon systems in Ogun waterside Local Government of Ogun State, Nigeria
}

\author{
A. A. IDOWU \\ Department of Aquaculture and Fisheries Management, University of Agriculture, Abeokuta, Ogun State, \\ Nigeria, E-mail: idowudoyin@yahoo.com
}

\begin{abstract}
A study was conducted to investigate the effects of some socio-economic activities such as beach seining, brush park fisheries and laundry activities on fish diversity, distribution and abundance over two years (dry and wet seasons) in lagoon systems of Ogun waterside Local Government Area, Ogun State, Nigeria. Structured questionnaire was used to obtain information on various activities in the study locations. Fish sampling from the catches from selected fishermen using assorted gears, physical and chemical characteristics of the lagoon systems were carried out in four selected stations based on activity. The study revealed that beach seine and laundry activities as socio-economic activities impacted negatively on fish diversity in Iwopin study location. Bagridae represented by Chrysichthys nigrodigitatus contributed the highest number of fish in the two seasons. Fish species were evenly distributed in the wet seasons than dry seasons. Simpson index (D) computed for the 4 sites are $0.15,0.11,0.62$ and 0.12 respectively for Makun-omi, Idaleketa, Iwopin and Ebute-Ilamo in the dry season and 0.37, 0.10, 0.42 and 0.10 for wet season. There are positive correlations between fish number, phosphate $(r=0.79)$ and Nitrate $(r=0.6)$. There are variations among physico-chemical parameters of water samples. Information gathered from this study is a useful tool for fisheries resource management of the lagoon systems of Ogun state.
\end{abstract}

(C) 2010 International Formulae Group. All rights reserved.

Key words: Fish resources, lagoon, season, socio-economic, Ogun waterside.

\section{INTRODUCTION}

Nigeria's ecosystem recently has come under increasing pressure and it is evident that ways must be found to raise production and incomes and at the same time learn how to better manage the biological resource base (NEST, 1991; Ezenwa and Ayinla, 1993). Ezenwa and Ayinla (1993), observed that Nigeria coastal brackish water systems in the Delta region (estuaries, lagoons, creeks and wetlands) which stretch approximately 850 $\mathrm{km}$ distance have witnessed human activities leading to the destruction of the critical grounds for nursery and decrease in fish landings from a peak of 500,000 metric tons a year in the seventies to less than 300,000 metric tons as from the late eighties to date.

Mndeme (1998) observed that for some years, the beautiful Tanzania marine environment and its resources have been 
under constant pressure from human activities based on the most deleterious practice of dynamite fishing.

Williams (1999) also observed that the world's fish stock are under heavy fishing pressures from both large and small scale fishers who own fishing gears from large commercial fleets fishing in the oceans to small individual fisher folks fishing in inland and near shore waters. These fishers are directly dependent on fishing and related activities as well as fish selling where any reduction in fishing efforts will have an immediate and indirect impact on their incomes especially where there are few alternative economic opportunities. There have been multiple studies that influence the establishment of priorities for biodiversity conservation projects.

Adams (1985) examined the downstream impacts of a dam and irrigation project in the Sokoto valley in the northern Nigeria. The Bakolori dam was built in the mid-1970s to supply a 30,000 hectare irrigation scheme. The dam reduced the magnitude of the wet season floods which supported an extensive and sophisticated agricultural system and a fishery upon which some 50,000 people depended. Reduced flooding caused a shift from rice to lowervalue millet and sorghum crops in the wet season and a significant reduction in the extent of dry season cultivation. Fish populations apparently declined and fishing decreased.

The increasing human population call for urgent need to protect whatever remains of the coastal estuaries and riverine wetlands which are important ecosystems for coastal urban inhabitants, oil producing companies, tourists, fish farmers and fishers. According to Arabatzis and Kokkinakis (2005) lagoon systems are places of great biological and ecological importance where fishery is the main economic activity in these ecosystems but intensive agriculture, industry and tourism have degraded their sensitive environmental structure.

There is a need to monitor human activities in the study sites in order to assess the healthy state of fisheries in the lagoon systems of Ogun waterside Local Government Area, Ogun state, Nigeria.

\section{MATERIALS AND METHODS \\ Description of study site}

The study was conducted along the lagoon stretch of Ogun waterside Local Government Area. The lagoon stretch is located between longitude $4^{\circ} 12 \mathrm{~N}-4^{\circ} 34 \mathrm{~N}$ and latitude $6^{\circ} 18 \mathrm{SE}-6^{\circ} 40 \mathrm{SE}$ on the map of Ogun waterside LGA, Ogun state, Nigeria (Figure 1). The lagoon borders the forest belt and receives a number of important rivers draining their waters into it.

\section{Experimental procedures Socio-economic data collection}

Four sampling sites, Makun-omi, Idaleketa, Iwopin and Ebute-Ilamo were randomly selected from the study area. Information on the socio-economic activities of the people was collected using questionnaire. Twenty-five fishermen in each of the four villages were randomly selected and structured questionnaire was used to obtain information on various activities on the lagoon stretch. Over a period of two years, fishing, beach seining and laundry activities were monitored, the data obtained was used to compare the present levels of fish exploitation. The various types and sizes of fishing gears used in fish exploitation as well as the type of fish species exploited in the past ten (10) years and other socio-economic activities that may have direct or indirect impact on the fish diversity of the lagoon waters were also assessed. Community Leaders of the study locations were interviewed to further elicit information on the status of fish diversity trends in the area to complement information from the questionnaire.

Determination of physical and chemical parameters of water samples

Temperature was determined using the ordinary mercury in glass thermometer calibrated in degree Celsius $\left({ }^{\circ} \mathrm{C}\right)$ (Boyd, 1979). The thermometer was dipped into the surface water from the boat for a depth of 20 $\mathrm{cm}$ and the value read off the mercury 


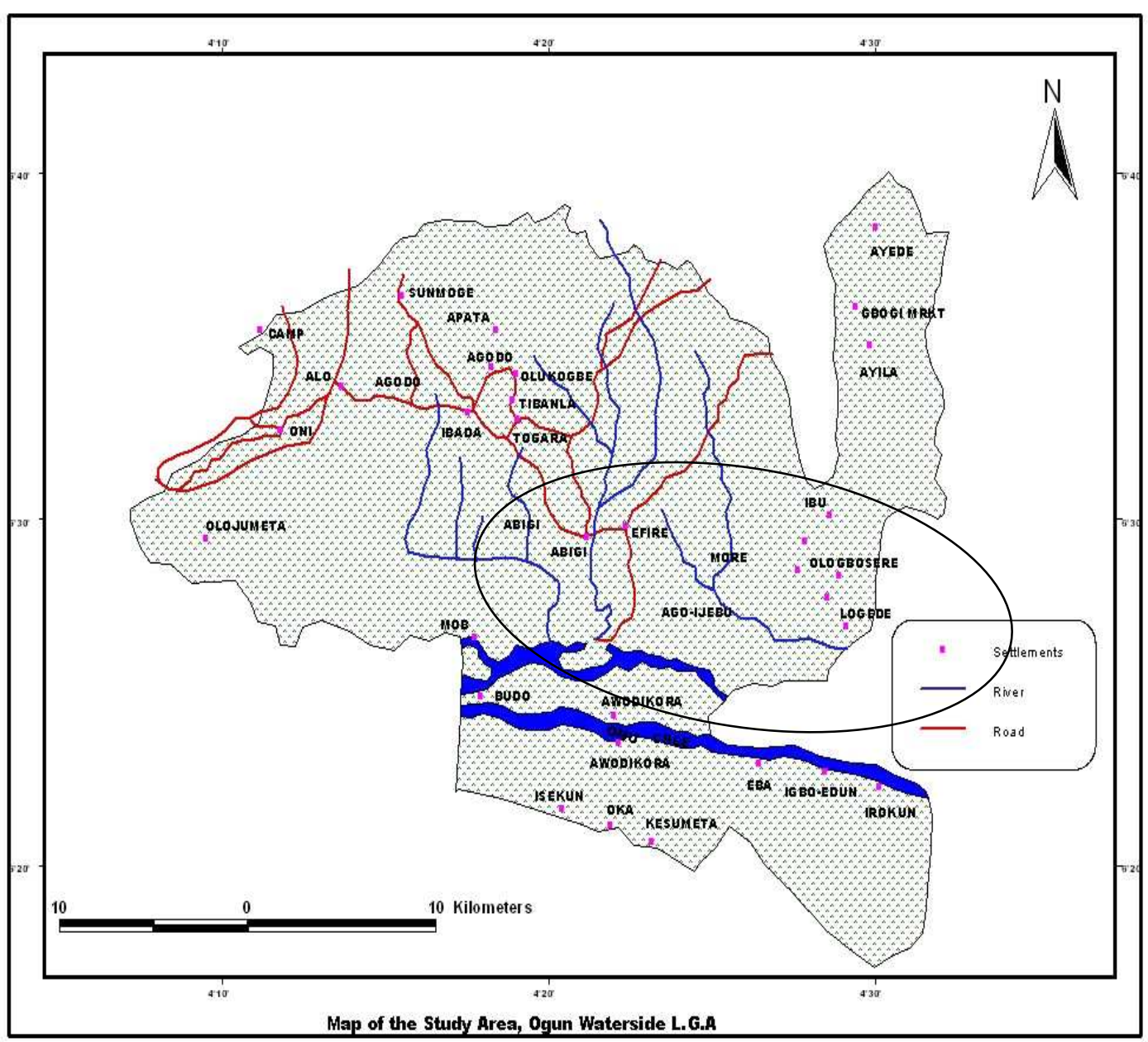

Figure1: Map of Ogun waterside LGA showing the lagoon systems of the study area.

line on the thermometer after the level was stable. Water transparency was determined using the Secchi disc. The Secchi disc was attached to calibrated rope and lowered from the boat slowly into the water until it disappeared and depth noted, it was then slowly pulled up and the depth at which the disc just reappeared was noted. The transparency value was taken as the mean values of the two readings and recorded for the study site. Dissolved oxygen was measured using dissolved oxygen meter model (Jenway DO 9071). The instrument was standardized by using saturated potassium chloride and zero solutions. The probe was then dipped from the boat into the water to record oxygen readings in situ for the various locations. Salinity of the collected water samples from the study sites was determined using Argentomeric method (APHA, 1998). $\mathrm{pH}$ of the water samples from the various locations was derived using a digital $\mathrm{pH}$ meter Suntex (model TS-2). This was first calibrated using 2 buffer solutions of 7 and 4. The nitrates level of the waters from the various locations was determined using Nitrate Electrode Method (APHA, 1998). The Ammonia level of the waters from the study sites was determined using Acidic method for Nitrogen (APHA, 1998). Phosphates level of the waters from the study sites was determined using Vanadomolybdophosphoric Acid Colorimetric method (APHA, 1998). 


\section{Statistical analysis}

Data collected on the socio-economic activities were analysed using descriptive statistics such as percentages while data collected on fish and water samples from the study sites were analysed using the following statistical procedures: Correlation analysis and Analysis of variance (ANOVA, One-way) where appropriate, in addition Least Square Design (LSD) was used to further bring out the differences observed among the means from the ANOVA.

\section{Determination of fish diversity}

The diversity indices used were:

i Species richness ( $S$ ), which is the total number of different fish species present.

Where $\mathrm{S}=\Sigma \mathrm{n} 1+\mathrm{n} 2+\mathrm{n} 3$

$+\ldots \ldots \ldots \ldots \ldots . . . n$ ni

ii Simpson index (D), which is the measurement that account for the percent of each species from a biodiversity sample within a local aquatic community. The index assumes that the proportion of individuals in an area indicates their importance to diversity.

Simpson index $(\mathrm{D})=\operatorname{Sum}(\mathrm{Pi})^{2}$ where $\mathrm{Pi}=$ the number of given species divided by the total number of fishes observed. The probability computed for each species is given in decimal percent.

\section{RESULTS}

The identified means of livelihood of the people in the study area were fishing with convectional nets and beach seining, logging and laundry activities (Table 1). Fishing was predominant in all the locations. Makun-omi, Idaleketa and Iwopin engaged more in logging activities. Analysis of the means of livelihood revealed that $(40.5 \%)$ of the respondents were into full time fishing out of which $25(12.5 \%)$ of the respondents were into brush park fishing especially Ebute-Ilamo, 61 (30.5\%) were into logging activities. Brush park fishing was identified as means of livelihood in Ebute-Ilamo with $25(12.5 \%)$ of the respondents engaged in the activity. The activity involves the use of aquatic plants such as Carex $s p$ to make fish fence trap round designated points in the lagoon. Baits such as $e b a$, earthworms and fish discards are used as attractants to lure fish into the brush park. The fishes are held for a period of six to ten months before they are harvested. According to the respondents the brush park system serves as fish refuge or fish aggregating device where fishes are held to maturity before harvest. This activity recorded 34 fish species and of importance is the abundance of Polypterus senegalensis in the catch which was not a common fish caught in other study sites. Brush park fishing as a socio-economic activity observed for a period of two years does not impact negative effect on the lagoon water except the discarded old fish fence trap dumped at the lagoon front which respondents believed has no influence.

The abundance and biodiversity indices composition of fish species in lagoon systems of the four sites, Makun-omi, Idaleketa, Iwopin and Ebute-Ilamo are presented in Tables 2,3 and 4. The Simpson diversity index (D) computed for Makun-omi, Idaleketa, Iwopin and Ebute-Ilamo were 0.15, 0.11, 0.62 and 0.12 respectively in the dry season. Simpson diversity index (D) computed for wet season for the four sites were $0.37,0.10,0.42$ and 0.10 respectively (Table 5). Fish abundance was higher in the wet season than that of dry season. The physico-chemical parameters of water samples in the 4 locations of the lagoon systems for both wet and dry seasons are presented in Tables 6 and 7. The highest mean temperature was recorded in Ebute-Ilamo $\left(28.6 \pm 2.2^{\circ} \mathrm{C}\right)$ while the least was $27.40 \pm 2.1{ }^{\circ} \mathrm{C}$ in Makun-omi in the wet season. Ebute-Ilamo recorded the highest mean value of $7.39 \pm 1.2 \mathrm{mg} / \mathrm{l}$ for dissolved oxygen while the lowest mean value was 3.77 $\pm 0.9 \mathrm{mg} / \mathrm{l}$ at Makun-omi in wet season. The peak record on salinity was recorded in Iwopin with $3.40 \pm 0.5 \%$ in wet season while the same study site recorded $3.69 \pm 0.3 \%$ in the dry season. Idaleketa recorded the highest value of $77.90 \pm 25.1 \mathrm{~cm}$ for water transparency in the wet season while the lowest was $73.1 \pm 27.3 \mathrm{~cm}$ at Ebute- Ilamo. 
Table 1: Summary of the observed frequencies on livelihood of the respondents on location basis in the study area.

\begin{tabular}{llclll}
\hline Location & Makun-omi & Idaleketa & Iwopin & Ebute-lamo & Total \\
\hline Fishing & 4 & 25 & 6 & 0 & 35 \\
Brush park fishing & 0 & 0 & 0 & 25 & 25 \\
Logging activities & 20 & 16 & 25 & 0 & 61 \\
Laundry & 1 & 1 & 0 & 0 & 2 \\
\hline
\end{tabular}

Table 2: Abundance of fish species sampled during the dry season in lagoon systems of the study area.

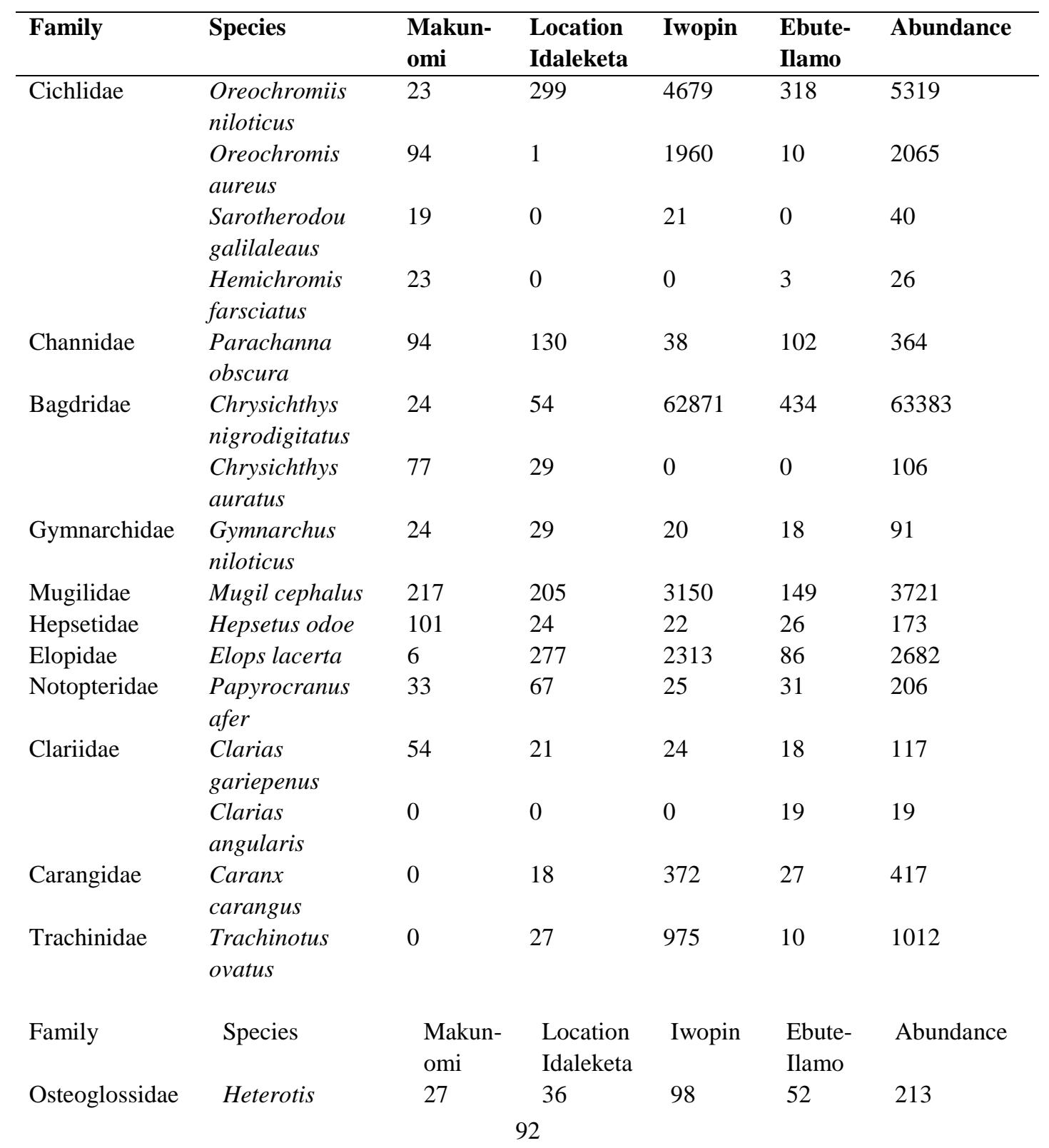




\begin{tabular}{|c|c|c|c|c|c|c|}
\hline \multirow{2}{*}{ Polypteridae } & \multicolumn{6}{|l|}{ niloticus } \\
\hline & $\begin{array}{l}\text { Polypterus } \\
\text { senegalensis }\end{array}$ & 129 & 0 & 4 & 104 & 237 \\
\hline \multirow[t]{4}{*}{ Mornyridae } & Mormyrops & 0 & 22 & 0 & 76 & 98 \\
\hline & deliciosus & & & & & \\
\hline & $\begin{array}{l}\text { Gnathonemus } \\
\text { abadii }\end{array}$ & 3 & 9 & 10 & 67 & 89 \\
\hline & Mormyrus rume & 3 & 0 & 0 & 0 & 3 \\
\hline Mochokidae & $\begin{array}{l}\text { Synodontis } \\
\text { clarias }\end{array}$ & 0 & 106 & 242 & 222 & 570 \\
\hline Sphraenidae & $\begin{array}{l}\text { Sphraena } \\
\text { piscartorum }\end{array}$ & 9 & 7 & 50 & 6 & 72 \\
\hline \multirow[t]{2}{*}{ Schilbeidae } & $\begin{array}{l}\text { Schilbe } \\
\text { senegalensis }\end{array}$ & 0 & 43 & 814 & 169 & 1026 \\
\hline & $\begin{array}{l}\text { Physalia } \\
\text { pellucida }\end{array}$ & 0 & 0 & 0 & 0 & 0 \\
\hline Polynemidae & $\begin{array}{l}\text { Galeiodes } \\
\text { decadactylus }\end{array}$ & 0 & 5 & 97 & 17 & 119 \\
\hline Lutjanidae & $\begin{array}{l}\text { Lutjanus } \\
\text { dentatus }\end{array}$ & 0 & 0 & 6 & 0 & 6 \\
\hline Trachinidae & $\begin{array}{l}\text { Trachinus } \\
\text { apmatus }\end{array}$ & 0 & 2 & 0 & 0 & 2 \\
\hline \multirow[t]{2}{*}{ Clupidae } & $\begin{array}{l}\text { Pellonula } \\
\text { afzeluisi }\end{array}$ & 1948 & 1012 & 100 & 25 & 3085 \\
\hline & $\begin{array}{l}\text { Ethmalosa } \\
\text { fimbriata }\end{array}$ & 235 & 36 & 45 & 0 & 316 \\
\hline Monodactylidae & Psettias sebae & 14 & 50 & 95 & 29 & 188 \\
\hline Characidae & Brycinus nurse & 651 & 77 & 573 & 260 & 1561 \\
\hline Pomadasyidae & $\begin{array}{l}\text { Pomadasys } \\
\text { jubelini }\end{array}$ & 1 & 32 & 574 & 9 & 616 \\
\hline Anabantidae & $\begin{array}{l}\text { Ctenopoma } \\
\text { kingslea }\end{array}$ & 14 & 3 & 49 & 70 & 136 \\
\hline Family & Species & $\begin{array}{l}\text { Makun- } \\
\text { omi }\end{array}$ & $\begin{array}{l}\text { Location } \\
\text { Idaleketa }\end{array}$ & Iwopin & $\begin{array}{l}\text { Ebute- } \\
\text { Ilamo }\end{array}$ & Abundance \\
\hline Cyprinidae & Barbus lagoensis & 37 & 30 & 5 & 60 & 132 \\
\hline Hemirgamphidae & $\begin{array}{l}\text { Hemiramphus } \\
\text { balao }\end{array}$ & 0 & 0 & 5 & 4 & 9 \\
\hline Cynoglossidae & $\begin{array}{l}\text { Cynoglossus } \\
\text { senegalensis }\end{array}$ & 0 & 0 & 1 & 0 & 1 \\
\hline Callinectidae & $\begin{array}{l}\text { Callinectes } \\
\text { pallidus }\end{array}$ & 72 & 11 & 0 & 11 & 94 \\
\hline Penaedae & $\begin{array}{l}\text { Peneaus } \\
\text { deuorarum }\end{array}$ & 0 & 28 & 2118 & 53 & 2199 \\
\hline
\end{tabular}


Table 3: Abundance of fish species sampled during the wet season in lagoon systems of the study area.

\begin{tabular}{|c|c|c|c|c|c|c|}
\hline Family & Species & $\begin{array}{l}\text { Makun- } \\
\text { omi }\end{array}$ & $\begin{array}{l}\text { Location } \\
\text { Idaleketa }\end{array}$ & Iwopin & $\begin{array}{l}\text { Ebute- } \\
\text { Ilamo }\end{array}$ & Abundance \\
\hline \multirow[t]{4}{*}{ Cichlidae } & $\begin{array}{l}\text { Oreochromiis } \\
\text { niloticus }\end{array}$ & 300 & 517 & 12384 & 506 & 13707 \\
\hline & $\begin{array}{l}\text { Oreochromis } \\
\text { aureus }\end{array}$ & 229 & 0 & 3768 & 0 & 3997 \\
\hline & $\begin{array}{l}\text { Sarotherodou } \\
\text { galilaleaus }\end{array}$ & 199 & 15 & 486 & 15 & 715 \\
\hline & $\begin{array}{l}\text { Hemichromis } \\
\text { farsciatus }\end{array}$ & 12 & 14 & 0 & 14 & 40 \\
\hline Channidae & $\begin{array}{l}\text { Parachanna } \\
\text { obscura }\end{array}$ & 521 & 195 & 285 & 228 & 1230 \\
\hline \multirow[t]{2}{*}{ Bagdridae } & $\begin{array}{l}\text { Chrysichthys } \\
\text { nigrodigitatus }\end{array}$ & 680 & 1568 & 208347 & 1510 & 212105 \\
\hline & $\begin{array}{l}\text { Chrysichthys } \\
\text { auratus }\end{array}$ & 1772 & 0 & 0 & 0 & 1772 \\
\hline Gymnarchidae & $\begin{array}{l}\text { Gymnarchus } \\
\text { niloticus }\end{array}$ & 118 & 154 & 29 & 154 & 455 \\
\hline Mugilidae & Mugil cephalus & 1964 & 296 & 661 & 296 & 3217 \\
\hline Hepsetidae & Hepsetus odoe & 287 & 97 & 7 & 97 & 488 \\
\hline Elopidae & Elops lacerta & 601 & 269 & 8312 & 269 & 9451 \\
\hline Notopteridae & $\begin{array}{l}\text { Papyrocranus } \\
\text { afer }\end{array}$ & 846 & 95 & 3 & 95 & 1039 \\
\hline \multirow[t]{2}{*}{ Clariidae } & $\begin{array}{l}\text { Clarias } \\
\text { gariepenus }\end{array}$ & 211 & 60 & 69 & 60 & 400 \\
\hline & Clarias angularis & 51 & 240 & 96 & 240 & 627 \\
\hline Carangidae & Caranx carangus & 152 & 54 & 429 & 54 & 689 \\
\hline Trachinidae & $\begin{array}{l}\text { Trachinotus } \\
\text { ovatus }\end{array}$ & 3 & 0 & 2410 & 0 & 2413 \\
\hline Family & Species & $\begin{array}{l}\text { Makun- } \\
\text { omi }\end{array}$ & $\begin{array}{l}\text { Location } \\
\text { Idaleketa }\end{array}$ & Iwopin & $\begin{array}{l}\text { Ebute- } \\
\text { Ilamo }\end{array}$ & Abundance \\
\hline Osteoglossidae & Heterotis niloticus & 65 & 355 & 9 & 283 & 712 \\
\hline Polypteridae & $\begin{array}{l}\text { Polypterus } \\
\text { senegalensis }\end{array}$ & 282 & 57 & 16 & 134 & 489 \\
\hline \multirow[t]{3}{*}{ Morniyridae } & $\begin{array}{l}\text { Mormyrops } \\
\text { deliciosus }\end{array}$ & 28 & 19 & 0 & 19 & 66 \\
\hline & $\begin{array}{l}\text { Gnathonemus } \\
\text { abadii }\end{array}$ & 98 & 50 & 0 & 50 & 198 \\
\hline & Mormyrus rume & 0 & 0 & 0 & 0 & 0 \\
\hline Mochokidae & Synodontis clarias & 80 & 163 & 4527 & 163 & 4933 \\
\hline Sphraenidae & $\begin{array}{l}\text { Sphraena } \\
\text { piscartorum }\end{array}$ & 143 & 27 & 462 & 27 & 659 \\
\hline \multirow[t]{2}{*}{ Schilbeidae } & $\begin{array}{l}\text { Schilbe } \\
\text { senegalensis }\end{array}$ & 406 & 88 & 8519 & 88 & 9108 \\
\hline & Physalia pellucida & 506 & 0 & 0 & 0 & 506 \\
\hline
\end{tabular}




\begin{tabular}{|c|c|c|c|c|c|c|}
\hline Polynemidae & $\begin{array}{l}\text { Galeiodes } \\
\text { decadactylus }\end{array}$ & 0 & 12 & 426 & 24 & 462 \\
\hline Lutjanidae & Lutjanus dentatus & 0 & 0 & 19 & 0 & 19 \\
\hline Trachinidae & $\begin{array}{l}\text { Trachinus } \\
\text { apmatus }\end{array}$ & 0 & 7 & 0 & 7 & 14 \\
\hline \multirow[t]{2}{*}{ Clupidae } & Pellonula afzeluisi & 16791 & 1158 & 526 & 145 & 18620 \\
\hline & $\begin{array}{l}\text { Ethmalosa } \\
\text { fimbriata }\end{array}$ & 0 & 515 & 108136 & 720 & 109371 \\
\hline Monodactylidae & Psettias sebae & 144 & 32 & 82 & 32 & 290 \\
\hline Characide & Brycinus nurse & 1339 & 173 & 302 & 217 & 2031 \\
\hline Pomadasyidae & $\begin{array}{l}\text { Pomadasys } \\
\text { jubelini }\end{array}$ & 0 & 8 & 272 & 8 & 288 \\
\hline Anabantidae & $\begin{array}{l}\text { Ctenopoma } \\
\text { kingslea }\end{array}$ & 100 & 682 & 0 & 846 & 1608 \\
\hline Family & Species & $\begin{array}{l}\text { Makun- } \\
\text { omi }\end{array}$ & $\begin{array}{l}\text { Location } \\
\text { Idaleketa }\end{array}$ & Iwopin & $\begin{array}{l}\text { Ebute- } \\
\text { Ilamo }\end{array}$ & Abundance \\
\hline Cyprinidae & $\begin{array}{l}\text { Barbus } \\
\text { lagoensis }\end{array}$ & 0 & 11 & 26 & 34 & 71 \\
\hline Hemiramphidae & $\begin{array}{l}\text { Hemiramphus } \\
\text { balao }\end{array}$ & 0 & 0 & 92 & 9 & 101 \\
\hline Cynoglossidae & $\begin{array}{l}\text { Cynoglossus } \\
\text { senegalensis }\end{array}$ & 0 & 0 & 2 & 0 & 2 \\
\hline Callinectidae & $\begin{array}{l}\text { Callinectes } \\
\text { pallidus }\end{array}$ & 146 & 53 & 0 & 53 & 252 \\
\hline Penaedae & $\begin{array}{l}\text { Peneaus } \\
\text { deuorarum }\end{array}$ & 0 & 15 & 2122 & 15 & 2152 \\
\hline Phractolelamidae & $\begin{array}{l}\text { Phrachtolaemu } \\
\text { s ansorgii }\end{array}$ & 0 & 14 & 0 & 0 & 14 \\
\hline
\end{tabular}

Table 4: Summary of seasonal fish species richness of the study area.

\begin{tabular}{|c|c|c|c|c|}
\hline \multicolumn{5}{|c|}{ Seasonal fish species richness of the study area } \\
\hline & Dry & Wet & Dry & Wet \\
\hline Seasons/Year & $2004 / 2005$ & 2005 & 2005-2006 & 2006 \\
\hline \multicolumn{5}{|l|}{ Zone1 } \\
\hline Makun-omi & 20 & 29 & 28 & 32 \\
\hline Idaleketa & 28 & 32 & 30 & 33 \\
\hline \multicolumn{5}{|l|}{ Zone 2} \\
\hline Iwopin & 25 & 31 & 33 & 34 \\
\hline Ilamo & 27 & 31 & 31 & 34 \\
\hline
\end{tabular}


Table 5: Summary of computed seasonal fish species Simpson indices of the study area.

\begin{tabular}{lcc}
\hline \multicolumn{3}{c}{ Seasonal summary of fish species Simpson indices of the study area } \\
\hline Seasons & Dry & Wet \\
Locations & & \\
Makun-omi & 0.15 & 0.37 \\
Idaleketa & 0.11 & 0.10 \\
Iwopin & 0.62 & 0.42 \\
Ebute-Ilamo & 0.12 & 0.10 \\
\hline
\end{tabular}

Table 6: Physical and chemical parameters for wet seasons.

\begin{tabular}{lllll}
\hline & Maku-omi & Idaleketa & Iwopin & Ebute-Ilamo \\
& & & & \\
\hline Water Depth $(\mathrm{m})$ & $3.55 \pm 0.4$ & $3.28 \pm 0.4$ & $4.84 \pm 0.4$ & $2.70 \pm 1.3$ \\
Temperature $\left({ }^{\circ} \mathrm{C}\right)$ & $27.4 \pm 2.1$ & $27.4 \pm 2.1$ & $28.2 \pm 1.9$ & $28.60 \pm 2.2$ \\
$\begin{array}{l}\text { Dissolved oxygen } \\
(\mathrm{mg} / \mathrm{l})\end{array}$ & $3.77 \pm 0.9$ & $5.91 \pm 2.0$ & $6.47 \pm 1.7$ & $7.39 \pm 1.2$ \\
Water transparency & $73.50 \pm 20.7$ & $77.9 \pm 25.1$ & $76.6 \pm 19.3$ & $73.1 \pm 27.3$ \\
$(\mathrm{~cm})$ & & & & \\
Salinity $(\% 00)$ & $1.2 \pm 0.2$ & $1.77 \pm 0.5$ & $3.40 \pm 0.5$ & $3.17 \pm 0.6$ \\
pH & $5.9 \pm 0.9$ & $6.85 \pm 1.0$ & $6.55 \pm 1.8$ & $6.75 \pm 1.1$ \\
Nitrate $(\mathrm{mg} / \mathrm{l})$ & $0.02 \pm 0.001$ & $0.005 \pm 0.001$ & $0.1 \pm 0.01$ & $0.3 \pm 0.01$ \\
Phosphate $(\mathrm{mg} / \mathrm{l})$ & $2.29 \pm 0.2$ & $2.89 \pm 0.1$ & $5.80 \pm 0.4$ & $2.69 \pm 0.2$ \\
\hline
\end{tabular}

LSD Values calculated for means comparisons show that:

Water depth $(\mathrm{p}=0.001103)$ significant at 0.05 level

Temperature $(\mathrm{p}=0.2824)$ not significant at 0.05 level

Dissolved Oxygen $(\mathrm{p}=0.01155)$ significant at 0.05 level

Salinity $(\mathrm{p}=0.00073)$ significant at 0.05 level

Phosphate $(\mathrm{p}=0.0000195)$ significant at 0.05 level

Table 7: Physical and chemical parameters for dry seasons.

\begin{tabular}{lllll}
\hline & Maku-omi & Idaleketa & Iwopin & Ebute-Ilamo \\
\hline Water Depth $(\mathrm{m})$ & $3.14 \pm 0.2$ & $2.84 \pm 0.5$ & $3.02 \pm 0.3$ & $1.29 \pm 0.2$ \\
Temperature $\left({ }^{\circ} \mathrm{C}\right)$ & $28.9 \pm 1.7$ & $29.10 \pm 1.4$ & $29.5 \pm 2.4$ & $29.30 \pm 2.2$ \\
Dissolved oxygen $(\mathrm{mg} / \mathrm{l})$ & $3.64 \pm 1.1$ & $4.06 \pm 1.6$ & $5.67 \pm 1.1$ & $6.68 \pm 1.4$ \\
Water transparency $(\mathrm{cm})$ & $74.50 \pm 10.7$ & $75.25 \pm 6.9$ & $79.20 \pm 6.4$ & $75.50 \pm 14.7$ \\
Salinity $(\%$ ) & $1.28 \pm 0.2$ & $2.05 \pm 0.5$ & $3.69 \pm 0.3$ & $3.38 \pm 0.4$ \\
$\mathrm{pH}$ & $7.40 \pm 1.3$ & $7.90 \pm 0.8$ & $7.25 \pm 1.2$ & $6.55 \pm 1.2$ \\
Nitrate $(\mathrm{mg} / \mathrm{l})$ & $0.14 \pm 0.001$ & - & $0.2 \pm 0.001$ & - \\
Phosphate $(\mathrm{mg} / \mathrm{l})$ & $2.12 \pm 0.1$ & $1.56 \pm 0.2$ & $5.56 \pm 0.1$ & $2.65 \pm 0.2$ \\
\hline LSD Values calculated for means comparisons show that: & & \\
Water depth $(\mathrm{p}=0.000091)$ significant at 0.05 level & & & \\
Temperature $(\mathrm{p}=0.401)$ not significant at 0.05 level & & & \\
Dissolved Oxygen $(\mathrm{p}=0.0006)$ significant at 0.05 level & & & \\
Salinity $(\mathrm{p}=0.000311)$ significant at 0.05 level & & & \\
Phosphate $(\mathrm{p}=0.0000151)$ significant at 0.05 level & & &
\end{tabular}


The peak value of $5.56 \pm 0.4 \mathrm{mg} / \mathrm{l}$ for phosphate was recorded in Iwopin in dry season. Phosphates values across the locations showed significant difference $(\mathrm{p}<0.05)$ in the two seasons. There are positive correlations between fish numbers and some physicochemical parameters such as phosphates $(\mathrm{r}=$ 0.79) and Ammonia $(r=0.6)$ in the two seasons.

\section{DISCUSSION}

The socio-economic activities revealed in the study area include fishing, logging activities and laundry. Fishing was the predominant activity in all the locations. The fishermen fish exclusively in lagoon using various fishing gears. Fishing as means of livelihood was by $40.5 \%$ out of which $12.5 \%$ practiced brush park fisheries. The fishing intensity at Iwopin using undesirable fishing gears such as beach seine and mosquito nets have led to catching of undersize fish especially Chrysichthys nigrodigitatu with $6.6 \pm 0.01 \mathrm{~g}$ average weight and the attendant low fish diversity in these locations. This finding agrees the observation of Albaret et al 2004, who recorded low fish catch at Gambia estuary as a result of high fishing intensity using beach seine. Logging activities as means of livelihood was practiced by $30.5 \%$ of respondents from Makun-omi, Idaleketa and Iwopin, where the logs were tied into rafts and held for dry season periods. This activity recorded high fish species in the dry season and is explained by the aggregating behaviour of the fish around the logs to seek for refuge. The fishermen encircled the logging area with nets and captured mature fishes especially Papyrocranus afer, Oreochromis niloticus species. This observation agrees with the finding of Venkatasami (1990), who noted that in the South East Asian area and in the Western Pacific, important quantities of fish are caught during well known seasons of drift of flotsam. Makun-omi, Idaleketa nd Iwopin recorded high fish species in the dry season that can be explained by the fish aggregating around the logging holding area. This finding agreed with findings of Venkatasami (1990), who observed that fishermen caught more fish around the floating rafts in South West Indian ocean.

The water depth of the study sites which range from $2.70 \mathrm{~m}-4.84 \mathrm{~m}$ in wet season and $1.29 \mathrm{~m}-3.14 \mathrm{~m}$ in dry season agrees with the observation of Ajani (2001) who recorded highest depth value of $5.5 \mathrm{~m}$ in wet season but the $0.5 \mathrm{~m}$ value recorded for dry season was too low compare to the one recorded at the study sites. This variation is probably due to short break that exist between the wet and dry season period. There was a positive correlation with rainfall which means that the water level rises with rain intensity. The water surface temperature values of the study sites were generally uniform across the sites in both seasons. The variation was less than $2{ }^{\circ} \mathrm{C}$. This observation conforms to other previous workers (Oyewo, 1998; Ajani, 2001; Chukwu and Nwakwo, 2003; Ajibola et al., 2005). Ajibola et al. (2005) recorded temperature range values of $27{ }^{\circ} \mathrm{C}-29{ }^{\circ} \mathrm{C}$ in the lagoon; they noted that at this temperature physical, chemical and biological properties in the waters are affected. The water temperature values also conform to the values recorded for tropical waters in which fishes thrive (Longhurst, 1968; Ceda, 1997). Boyd (1979) also noted that warm water fishes grow best at temperature between $25{ }^{\circ} \mathrm{C}$ and $32{ }^{\circ} \mathrm{C}$. The dissolved oxygen levels were higher in wet season than dry season this is probably due to the influx of adjoining rivers that flow into the lagoon. There was a negative correlation between the dissolved oxygen and temperature. This observation disagrees with the findings of Ajani (2001) who recorded positive correlations between dissolved oxygen and temperature. The high levels of dissolved oxygen observed from the study sites agrees with Boyd and Lichtkoppler (1985) who reported that the oxygen concentration level above $5.00 \mathrm{mg} / \mathrm{l}$ as the desirable level for most fish species. The salinity values recorded for the sites were generally higher especially during the dry season; the salinity is typical of estuary/lagoon that is closer to marine 
locations. The high salinity value is probably due to low discharge of water and the slightly low value of salinity in wet season may be due to dilution rate of the rainfall and discharge of fresh water from adjoining rivers. This observation agrees with those of Olaniyan (1969), Dublin-Green (1990) and Oyewo (1998).

\section{Conclusion}

The study revealed that socio-economic activities such as beach seining and laundry activities impacted negatively on fish diversity especially at Iwopin. The number of fish species observed in the study showed some level of richness in the fish diversity of the study sites. Chrysichthys nigrodigitatus was the most dominant fish species caught in the dry and wet season in the study sites. The physical and chemical parameter values recorded for the study area supported the biological life in the lagoon systems and thus enhance the fish abundance and distribution. Human activities need to be monitored to sustain aquatic life. The information and observation of the study will be useful in formulating the rational exploitation of fish species especially Chrysichthys nigrodigitatus and conservation of less abundant fish species.

\section{REFERENCES}

Adams WM. 1985. The Downstream Impacts of Dam Construction: A Case study from Nigeria. Transaction Institute of British Geographers., 10: 292 - 301.

Ajani EK. 2001. Effects of Biotic and Abiotic components of the habitat on fish productivity in Lagos Lagoon, Nigeria. PhD thesis, University of Ibadan, p. 277.

Ajibola VO, Funtua II, Unuaworho AE. 2005. Pollution Studies of Some Water bodies in Lagos, Nigeria. Caspian J. Env. Sci., 3(1): 49-54.

Albaret JJ, Monique S, Famara SD, Jean-Marc E, Raffray J, Titode Morais L. 2004. Fish diversity and distribution in the Gambia Estuary, West Africa, in relation to environmental variables. Aquatic Living Resources., 17: 35-46.
APHA 1998. Standard methods for the examination of water and waste water. American Public Health Association (APHA). Water Pollution Control Federation, Washington D.C., p. 1193.

Arabatzis GD, Kokkinakis AK. 2005. Typology of the lagoons of Northern Greece According to their Environmental characteristics and fisheries Production. ORIJ Contents, 5(1): 114-118.

Boyd CE, Lichtkoppler F. 1985. Water quality management in pond fish culture. Research and Development Series 22. International Center for Aquaculture Agriculture Experiment Station. Auburn University, Auburn, Alabama. p. 30.

Boyd CE. 1979. Water quality in warm water fish ponds. Auburn University, Agric. Expt. Station, Auburn, Alabama. p. 361.

Ceda 1997. Coastal Profile of Nigeria: In Federal Environmental Protection Agency. Large marine ecosystem project for the Gulf of Guinea. Cotonou, Benin, p.33.

Chukwu LO, Nwakwo DI. 2003. The Impact of Land based pollution on the Hydrochemistry and macrobenthic community of a tropical West African creek. In Diffuse Pollution Conference Dublin, 6: 67-6.72.

Dublin-Green CO. 1990. Seasonal variations in some physico-chemical parameters of the Bonny estuary, Niger Delta. NIOMR Tech. Paper, 591: 5.

Dublin-Green CO, Tobor JG. 1992. Marine resources and activities in Nigeria. NIOMR Tech. Paper. 84: 25.

Ezenwa BI. Ayinla AO. 1993. Conservation Strategies for Endangered Fish Species Breeding and Nursery Grounds within the Coastal Wetlands of Nigeria. Proceeding of the National Conference on Conservation of Renewable Resources, National Resources Conservation Council (NARESCON). p. 51-56.

Longhurst AR. 1968. The coastal oceanography of western Nigeria. Bull:IFAN., 26: 337-402. 
Mndeme YES. 1998. Efforts to Save the Marine Environment in Tanzania. THE ICLARM Quarterly, July-September 1998. p. 35.

N. E. S. T. 1991. In Nigeria's Threatened Environment. A National profile. Nigerian Environmental Study/ Action Team (N. E. S. T.) publication, p.288.

Olaniyan CIO. 1969. The seasonal variations in the the hydography and total plankton of the lagoons of South west Nigeria. Nig.J.Sc., 3(2): $101-119$.

Oyewo EO. 1998. Industrial sources and Distribution of Heavy metals in Lagos
Lagoon and their biological effects on Estuarine Animals. PhD Thesis University of Lagos, p.279.

Simpson EH. 1949. Measurement of Diversity. Nature., 163: 688.

Venkatasami R. 1990. Introduction of fish aggregating devices in the Southwest Indian Ocean (A case study). SV/49-IPFC Symposium on Artificial Reefs and Fish Aggregating Devices (Fads) as Resources Enhancement and Fisheries Management Tools, Colombo, Sri Lanka.p. 28.

Williams MJ. 1999. Four Blocks to Controlling Fishing Pressure. The ICLARM Quarterly, 22(4): 2. 